\title{
GÜVENLİ KENT VE KENT GÜVENLİĞİ ÜZERİNE BİR İRDELEME
}

\author{
Correspondent Author: Esmeray ALACADAĞLI
}

An Investigation on Safe City and Urban Security

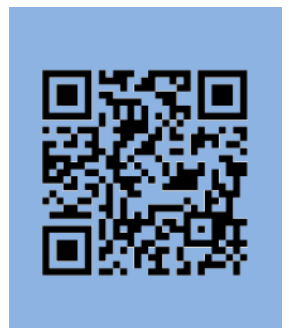

Esmeray Alacadăg $l_{l}^{1}$

MAKALE BILGISI
Makale Geliş Tarihi : 16/11/2020
Makale Kabul Tarihi : 16/12/2020
Anahtar Kelimeler:Kent,
Güvenli Kent, Cazibe
Merkezi, Liberal Ekonomi
Politikaları

JEL Kodları:

JEL kodu O18,JEL kodu O20, JEL R58

\section{ARTICLE INFORMATION}

Submission Date $\quad: 16 / 11 / 2020$ Accepted Date $\quad: 16 / 12 / 2020$

Keywords:City, Safe City, Liberal Economic Policies, Attraction Center
Kentler, insanların yerel ve ortak gereksinimlerini karşılamak üzere biraraya gelmeleriyle oluşan mekanlardır. Kentler, geçmişten günümüze pek çok ulus ve kültürden insana; fiziksel, ekonomik ve sosyal açılardan örgütlenerek birarada yaşama olanağı sağlamıştır. Birçok tarihçi ve kentbilimci; insanlığın değişim ve dönüşümün izlerinin sürüldüğü uygarlık tarihi ile kent tarihini özdeşleştirir. Onlara göre bu iki alanda yaşanan süreçler birbirine paralel gitmiştir. Sanayileşme, bilimsel ve teknolojik gelişmeye bağlı olarak ortaya çıkan küreselleşme ve uluslararası sermaye hareketleri, kentleri ekonomik, sosyal, hukuksal ve siyasal açılardan değiştirip dönüştürmüştür. $\mathrm{Bu}$ süreçte kentler, ulus devletten bağımsız olarak küresel ekonomiye eklemlenmeye başlamıştır.

Günümüzde kentleri ekonominin temel bir fonksiyonu olarak gören yaklaşımlar ve liberal ekonomi politikaları sonucu kentler; belli özellikleri öne çıkarılarak cazibe merkezleri haline getirilmeye ve markalaştırmaya çalışılmaktadır. Uluslar arası ve ulusal sermayeden daha fazla pay almak, büyümek, gelişmek isteyen kentler de kendilerini özellikle bir konuda uzmanlaşmaya ve öne çıkarmaya zorlamaktadır. $\mathrm{Bu}$ nedenle bazen kent yönetimlerince bazen de uluslararası kuruluşlarca kentler; güvenli kent, huzurlu kent, akıllı kent gibi sifatlar eklenerek tanımlanmakta ve pazarlanmaktadır. $\mathrm{Bu}$ çalışmanın amacı; küreselleşen dünyada liberal ekonominin kurallarına göre öne çıkmak, cazip hale gelmek, uluslar arası ve ulusal sermayeden daha fazla pay almak üzere; kent yönetimi ya da ulusal ve uluslar arası kuruluşlarca kentlere atfedilen tanımlamaların, kentlerin kendi gerçekliği ve uygulamalarıyla ne ölçüde örtüştüğünü, kendini "güvenli kent" diye tanımlayan Bayburt örneğinde ortaya koymaktır.

Cities are places where people come together to meet their local and common needs. Cities are provided the opportunity, from past to present for many nations and cultures, to live together by being organized in physical, economic and social aspects. Many history and urban scientists identify civilization history with urban history where the traces of change and transformation of humanity. According to them, the processes experienced in these two areas went parallel to

1 Dr. Öğr. Üyesi, Bayburt Üniversitesi, İİBF Siyaset Bilimi ve Kamu Yönetimi Bölüm ORCID Number: https://orcid.org/0000-0003-1604-6487,onad@web.edu.tr 


\section{Araştırma Makalesi, DOI: 10.46849/guiibd.826821}

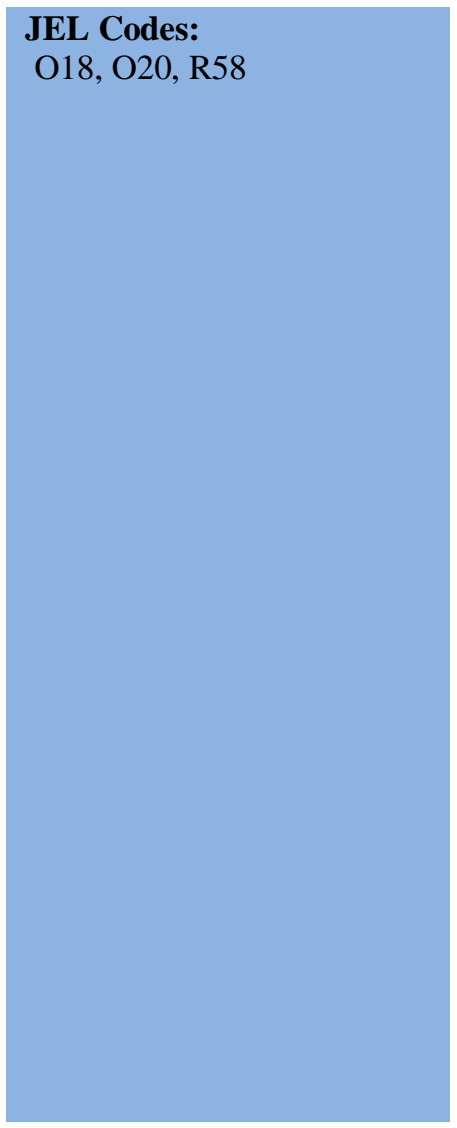

each other.

Globalization and international capital movements that emerged due to industrialization, scientific and technological development have transformed cities in economic, social, legal and political aspects. In this process, cities have begun to join the global economy independently of the nation state.

Today, as a result of approaches that perceive cities as a fundamental function of the economy and liberal economic policies, cities are tried to be turned into attraction centers and branded by highlighting certain features. Cities that want to get more shares from international and national capital, grow and develop, force themselves to specialize and come forward. For this reason, cities are defined and marketed by adding adjectives such as safe city, peaceful city, smart city, sometimes by city administrations and sometimes by international organizations. The aim of this study is; to stand out according to the rules of the liberal economy in the globalizing world, to make the city attractive, to get more shares from international and national capital; to reveal the extent to which the definitions attributed to cities by the city administration or national and international organizations coincide with the reality and practices of cities in the example of Bayburt, which defines itself as "a safe city".

\section{Giriş}

Güvenlik insanlar için olmazsa olmaz, en temel ihtiyaçlardan biridir. Abraham H. Maslow'un "Temel İhtiyaçlar Piramiti”"nde ilk sırada yer alan beslenme, barınma gibi temel ihtiyaçlardan hemen sonra gelen güvenlik ihtiyacı; bireylerin emniyet içinde ve çatışmadan uzak yaşamaya yönelik gereksinimlerini içerir (Kula ve Çakar, 2015:193). TDK Sözlüğü'nde güvenlik kavramı; “Toplum yaşamında yasal düzenin aksamadan yürütülmesi, kişilerin korkusuzca yaşayabilmesi durumu, emniyet" (TDK, 2005: 817) olarak tanımlanır. Bir başka tanıma göre güvenlik; "birey açısından kişilerin kendini güvende hissetmesi, emniyet birimleri acısından ise toplumsal yaşamda yasal düzenin aksamadan yürütülmesi, kişilerin korkusuzca yaşayabilmesi durumudur" (Aytaç vd.,2015: 260).

2000'li yıllar öncesinde politik açıdan belirlenen ilkelerde ve yapılan uygulamalarda güvenlik denildiğinde, asayiş algısına odaklanıldığı gözlemlenmektedir. Asayiş: "bir yerin düzen ve güvenlik içinde bulunması durumu olup suç olaylarının aydınlatılması ve suçluların adalete teslimi gibi faaliyetleri içermektedir (Aytaç vd.,2015, s.260). Sonuç olarak; emniyet, asayiş, hangi açıdan bakılırsa bakılsın güvenlik giderilmesi gereken temel bir ihtiyaçtır. Bu bağlamda insanlar, tarihin her döneminde güvenlik gereksinimlerini gidermek, emniyet ve güvenlik içinde yaşamak için bir araya gelmişler, bunun için, idari, siyasi çeşitli yapılar oluşturmuşlardır.

Kentler ve devletler, insanların güvenlik konusundaki temel gereksinimlerini gidermeye yönelik faaliyetlerin, örgütlenmelerin bir sonucu olarak ortaya çıkmıştır. Bir 
başka şekilde ifade etmek gerekirse kentler; geçmişte ve günümüzde insanların bir arada güvenlik içinde yaşama isteğinin ortaya çıkardığı mekânsal yerleşimlerdir. Tarihsel süreçler boyunca insanlar korunma güdüsüyle bir araya gelerek kentler kurmuşlar ve kentte oluşturdukları ortak yaşamla kendilerini güvende hissetmişlerdir (Kaypak, 2016: 36). Günümüzde de insanlar kent, ya da kırsal alanlarda köy adı verilen yerleşim yerlerinde, barınma, çalışma ve dinlenme ihtiyaçlarını gidererek yaşamlarını sürdürmektedir.

Kent, nüfusu belli bir büyüklüğü ve yoğunluğu aşan, ekonomisi tarım dış1 etkinliklerde yoğunlaşan (Keleş, 2016: 109-111) ve kendi nüfusundan başka etki alanı içinde yaşayanlara da hizmet sağlayan yerleşim birimidir. Günümüz kentleri, modernleşme ve sanayileşme süreciyle ortaya çıkmış olup 7,4 milyara ulaşan tüm Dünya nüfusunun yarıdan fazlası (\%54'ü) kentlerde yaşamaktadır (Sümer, 2018: .466). Doğası gereği yoğun, çok sınıflı ve örgütlü insan yerleşimlerini barındıran heterojen yapıdaki bu mekânsal yerleşimler, güvenlik ihtiyacının en çok duyumsandığı yerlerdir. Çünkü sanayileşmeye dayalı hızlı nüfus artışı ve kırdan kente göçlere bağlı olarak artan kent nüfusu ve sağllksız kentleşme sonucu kentlerin güvenliğini de sağlamak giderek zorlaşmıştır (Kaypak, 2016: 36). Öte yandan kentsel güvenlik konusunda kavramsal açıdan da farklılaşmalar söz konusudur.

Günümüzde kent güvenliği, asayişi ön plana alan yaklaşımla suç unsurlarını ortadan kaldırarak emniyeti sağlamak olarak görülmeyip, bir hak olarak kent sakinlerinin güvenli bir kentsel çevrede yaşamaya yönelik haklarını da kapsamaktadır. $\mathrm{Bu}$ açıdan bakıldığında; bütün insanların insan olmaktan kaynaklanan yaşam hakkı, bütün hakların kaynağını ve sağlıklı güvenli bir kentte yaşamanın temelini de oluşturmaktadır. Günümüzde, güvenli kentlerle kastedilen ve beklenilen; bir insan hakkı olup içinde bilgi hakkı, ifade hakkı, kültür hakkı, farklı ve eşit kimlik hakkı, kent yönetimine katılım hakkı gibi hakları barındıran ve üçüncü kuşak haklar kapsamında düzenlenen "Kentli Hakları"nın (Ertan, 2014: 54-62) hayata geçebilmesini sağlayacak şekilde donanımlara, araçlara sahip ve bu anlayışla oluşturulan kentlerdir. Avrupa Konseyi'nce 1992 'de benimsenen belgede; ideal bir kentin kentli haklarını güvenceye alabilecek her tür donanım, sağlıklı çevre, iş sosyal ve kültürel yaşam alanlarına sahip bir kent olduğundan söz edilerek (Alacadağl1, 1998: 667), "her kent sakininin, mümkün olduğunca suç, kabahat ve saldırılardan arındırılmış emin ve güvenli bir kentte yaşama hakkına sahip" olduğu belirtilmektedir (Payam, 2018: 17).

Kent yöneticilerince, beş bin yıllık tarihi geçmişi olmanın yanında huzurlu ve güvenli bir kent olarak tanımlanan Bayburt'ta 2008 yılında kurulan Bayburt Üniversitesi’nin de sloganı “'Güvenli Şehrin Huzurlu Üniversitesi’dir. Yukarıda değinildiği üzere güvenli kentler, tüm insanlar ve toplumlar için temel bir ihtiyaç olan güvenliğin yanı sıra günümüzdeki anlamı ile üçüncü kuşak hakların kullanımı için de gereken tüm koşulları sağlayan kentlerdir. Bu çalışma; Bayburt kenti örneğinde, kentlerin kendilerini tanımlamada kullandığı sloganların o sloganların gerektirdiği koşulları sağlayıp sağlayamadığını ve bu koşulların sağlanabilmesi için yapılması gerekenleri ortaya koymak amacıyla yapılmıştır. Bu kapsamda yapılan literatür taramasıla; güvenlik, kent güvenliği, güvenli kent gibi kavramsal çerçeve ile Bayburt'la ilgili ve çalışma konusunun gerektirdiği verilere ulaşılmıştır. Güvenli kent ve kent güvenliği kavramlarının anlam ve içerik olarak farklılığ 1 konusunda kent yöneticileri ve kent halkının farkındalığı, güvenli kentten anlaşılanın ne olduğunu belirlemek üzere kent yöneticileri ve kent halkına yönelik mülakat ve soru kağıdı 
uygulanmıştır. Literatür taraması ile uygulanan anket ve mülakatların birlikte değerlendirmesiyle sonuca ulaşılmış ve öneriler geliştirilmiştir.

\section{Yasal Düzenlemelerde Kent Güvenliği ve Güvenli Kent Yaklaşımı}

Kentleşme dar anlamda kent sayısının ve kentlerde yaşayan nüfusun artmasını anlatır (Keleş, 2016: 37). Ancak bu tanımda kentleşmenin toplumun ekonomik ve sosyal yapısındaki yol açtığı kente özgü davranışların benimsenmesi boyutu yer almamaktadır. Kentleşme genelde bir değişme ve örgütlenmeyi içeren bir süreçtir ve sosyo kültürel sonuçları vardır. $\mathrm{Bu}$ sonuçlardan en önemlisi kente özgü bir yaşam tarzının ortaya çıkmasıdır. Bu bağlamda kentlileşme kavramı; büyük ölçüde sosyal değişimle birlikte olsa da asıl olarak kentteki bireylerin geçirdiği kültürel değişimi tanımlar. Kentlileşme bu değişimin ortaya çıkardığı bir sonuç olup bir bütün olarak toplumun kent kültürüne sahip olması anlamına gelmektedir. Kent yaşam biçimiyle özdeşleşmeyi anlatan kentlileşmenin temel öğeleri; ailenin biçimsel olarak küçülmesi, akrabalık ilişkilerinin zayıflaması, kadının aile içindeki rolünün değişmesi ve ekonomik bağımsızlığını elde etmesi, ailedeki kimi temel fonksiyonlarının toplumsal kurumlara devredilmesi, tüketim harcamalarının artması, geleneksel iş ve boş zaman değerlendirme alışkanlıkları kazanılması ile komşuluk ilişkileri, dinlenme, eğlence ve benzer alanlardaki tutum ve davranışlarda değişim olarak özetlenebilir. Bir başka ifadeyle kentleşme, sadece ekonomik ve fiziki bir örgütlenme olmayıp aynı zamanda ona özgü düşünce ve davranışları olan bir toplumsal düzendir. $\mathrm{Bu}$ düzenin kurulabilmesi için uygarlaşma, sosyalleşme, katılım, kültürel ve estetik değerlere yönelik ilkelerin o kentte yaşayanlarca benimsenmesi ve uygulamaya geçirilmesi gerekir. Kentlileşme denilen bu süreç sağlıklı gelişebildiği ölçüde orada kentleşmenin sağlandığından söz edilebilir.

Kentleşme denilince geçmişte; sanayileşme, sanayi toplumu ve bu toplumun gerektirdiği yapılar ve değerler gelirken günümüzde küreselleşme, teknolojik gelişme, bilgi toplumu onun gerektirdiği değerler ve toplumsal yapı gelmektedir. Günümüz kentleri sürdürülebilirliğini sağlamak için bilgiye dayalı ve bilgiyi üreten bir yaşam biçimine geçmek ve onun gerektirdiği uygulamaları yaşama geçirmek durumundadır.

Günümüzde, kent sayıları artmakta ve kentli nüfus hızla büyümektedir. Kentlerin büyümesinin ve kentli nüfusu artırmasının yol açtığı sorunlardan biri de kentleşmenin, kente özgü davranış ve tutumların benimsenmesi sürecini, yani "kentlileşme"yi yavaşlatırken kentin birçok güvensizlik unsurunu barındırır hale gelmesidir. Kentsel alanlar, güvenlik ihtiyacının daha yoğun hissedildiği mekânlardır. Çünkü kentleşme süreçleri ve yoğun göçlerle kent nüfusu hızla artarken, farklı yaşam biçimleri ve kültürlerin kente yerleşmesiyle, kentin homojenliği de azalmaktadır. Farklı kültür, eğitim, gelir düzeyinden kişiler kent nüfusunu artırmanın yanında kentte işlenen suç sayılarını ve çeşitlerini de artırmaktadır. Kentleri güvensiz kılan ve güvenlik gereksinimini daha yoğun hissettiren sorunlardan biri de bu "kentlerdeki suç" olgusudur. Farklı yaşam standartlarında yaşamlar, beklentileri gerçekleştirmek için uygun araçlara sahip olamamanın yarattığı ümitsizlik ve çaresizlik duyguları, işsizlik, ekonomik sorunlar, daha fazla oranda kanun dışı yolların kullanılmasına neden olmaktadır (Derdiman, 2010:53). Daha güvenli yaşamak üzere bir araya gelinen kentlerin güvenlik konusunda yaşadığı sorunlar güvenlik anlayışı alanlarını da değiştirmektedir. 
Kent güvenliği; önleyici kolluk faaliyetlerinin kentsel alanlarda uygulanmasinı anlatan bir kavramdır (Payam, 2018: 22). Kolluk gücü olarak bakıldığında; "kentlerde kamu düzenini sağlamak ve kent sakinlerinin temel hak ve özgürlüklerini koruyarak huzur içinde yaşamalarını sağlayacağı ortamları hazırlamak ve bu ortamın sürekliliği için gerekli önlemleri almak temelde devletin görevidir (Toprak, 2014: 3-10). Devlet bu temel görevini eğer kentlilerin beklediği şekilde karşılayamazsa çalışma, sosyalleşme, kişisel gelişimini sağlama, kendini gerçekleştirme gibi diğer gereksinimler de ihtiyaç olmaktan çıkar. Çünkü çalışabilmek için önce bireyin/kent sakininin can ve mal güvenliği sağlanmalıdır. Maslow'a göre bir önceki ihtiyaç karşılanmadan bir sonraki basamağa geçilemeyeceğinden, güvenlik ihtiyacı karşılanmamış hiçbir birey, daha üst basamaklara geçemez, çalışmaya, sosyalleşmeye, iş ve özel yaşamında kişisel gelişimini tamamlamaya yönelik aşamaları yapma başarısını gösteremez. Bundan dolayı güvenlik hizmeti, bireysel olarak da toplumsal yaşam açısından da önemi büyük olan bir kamu hizmetidir.

Güvenlik en genel anlamda kasıtlı olaylara karşı koruma olarak ifade edilirse, kent açısından güvenlik ya da kent güvenliği; insanların kasten hareket ettiği olaylardan kent sakinlerinin korunması, kent sakinlerini etkileyebilecek insan kaynaklı risk ve tehditlere karşı korunmanın sağlanmasıdır. Kentsel güvenlik, çeşitli yapısal ve yerel faktörlere bağlı olup genellikle, kentlerde işlenen suçların önlenmesi ve bunlara müdahale edilmesine yönelik faaliyetler, programlar ile incelenir ve izlenir. $\mathrm{Bu}$ bağlamda kentsel güvenlik iki ana temaya odaklanır: Bunlardan biri kent sakinlerinin bütünlügü içinde güvenliğidir ve bu bağlamda kent alanlarının artan militarizasyonuna bağlı olarak kentlinin bireysel güvenliğini içerir. Diğeri ise; kentlerin bir bütün olarak güvenliğidir (Payam, 2018: 22). Kent güvenliği bağlamında temel risk faktörleri genel olarak; gasp/çalma, uyuşturucu kaçakçılığı, hırsızlık, soygun, tecavüz, cinayet, adam kaçırma, dolandırıcılık, insan kaçakçılığı, fuhuş vb suç ile ilgili olaylar; yurtiçi, uluslararası ve sınır ötesi terörizm, sınır ötesi, sınır savaşı, yıpratma ve sivil savaş şeklindeki savaşlar, darbe, şiddet gösterileri, isyan ve ayaklanmalar gibi sivil/siyasi huzursuzluklar şeklinde sinıflandırılabilir. Kentlerde güvenlik herkesin endişesidir. Kentli hakkına, orada yaşayanların güvenliği garanti edilmeden ve suç korkusu azaltılmadan, gerçek anlamda tamamen sahip olunamaz.

Güvenli kent yalnızca "suç oranlarının düşük olduğu kent" demek değildir. Güvenli kent kentlilerin kendilerini kentin herhangi bir noktasında, günün herhangi bir saatinde güvende hissettikleri kenttir. "Güvenli Kent Yaklaşımı; güvenli kenti oluşturabilmeye yönelik kent planlaması, bina tasarımları, trafik düzeni, kent bilgi ve güvenlik sistemleri, suça ilişkin sosyolojik, ekonomik, politik boyutlar dahil kentin tasarım ve gelişimine yön verirken güvenlik kaygılarını ve kamu düzenini göz önünde tutan, suçların önlenmesi için ideal sosyal ve fiziki koşulları sağlamaya çalışan, suç işlendikten sonra da suçluların yakalanmasını kolaylaştıran kentle ilgili aktivitelerinin tümüdür" (Gündüzöz, 2016: 335). Güvenli kentler, suçlarla etkin bir biçimde mücadele edilen, suç fursatlarının verilmediği, suçluların barınamadığı, çarpık yapılaşmanın olmadığı, içinde yaşayanların çağdaş uygarlık seviyesine ulaşma azim ve iradesini gösterdiği, mutlu olduğu, tüm gereksinimlerini karşılayabildiği ve yaşam kalitesinin yüksek olduğu mekânlar olarak görülürler. Bu kapsamda günümüzde güvenlik olgusu çağın anlayışına uygun bir biçimde ele alınmakta, kentlerde yaşayan halkın en temel insan ihtiyacı olan güvenliğinin sağlanmasına da çağın gerektirdiği bütünsel anlayışla yaklaşılmaktadır (Aytaç vd., 2015: 261). Kentlilerin daha güvenli alanlarda yaşama 
talepleri artık klasik kent güvenliği gibi dar bir kavramın çerçevelediği bir düzlemde karşılanmamaktadır.

Güvenli kent bütünsel yönetim anlayışına dayalı bir yaklaşım olup; kapsayıcı, multidisipliner ve önleyici politikaları benimser. $B M$ ve $A B$ tarafindan sahiplenilen bu yaklaşım Hollanda ve İngiltere' de doğmuştur. Önleyici davranış biçimleri temelinde şekillenir ve kentsel tasarımı, kentsel güvenliğin önüne alır. "Çevresel Tasarımla Suçun Önlenmesi (CPTED)" kuralına odaklanır. Hukuksal, yönetsel, imar/kentsel tasarım düzeyinde farklı uygulamaları gerektirir. Yönetişim temelli, sivil toplumun, birey farkındalığı ve katılımının her alanda kendini hissettirdiği siyasal kültüre sahiptir.

Güvenli kentlerle ilgili değerlendirmelerde farklı indeksler kullanılmaktadır. 40'tan fazla nicel ve nitel göstergeye dayanan Güvenli Kentler İndeksi'nde göstergeler; "dijital, kişisel güvenlik, sağlık ve altyapı güvenliği'" olarak dört tematik kategoriye ayrılmıştır. Bu indeksler içinde temel indeks ilk olarak "anahtar genel indeks"tir. Alt indeksler ise dijital güvenlik indeksi, sağlık güvenliği indeksi, altyapı güvenliği indeksi ve kişisel güvenlik indeksidir. Güvenli Kent Yaklaşımı; tüm bu kavramlarla da ilişkili olarak holistik ve kapsayıcı bir yeni yaklaşım olarak gelişmektedir. Güvenli Kentler İndeksi, Dünyada bölgelerini temsil yeteneği olan 50 kent için yapılmaktadır. Her bir kent bu dört kategori için puanlamaya tabi tutulur. Bu puanlama sonuçları Amerikan "The Economist' Dergisi tarafindan her yıl yayımlanır. Araştırma kapsamında Türkiye'den İstanbul da yer almaktadır. Örneğin, İstanbul Kenti, anahtar genel indeks suralamasında 41, dijital güvenlik indeksinde 49, sağlık güvenliği indeksinde 46. sirada yer almaktadır (Gündüzöz, 2016: 343).

Ülkemizde bu konuda var olan yasal düzenlemeler ve uygulamalar daha çok kent güvenliği çerçevesinde biçimlenmektedir. Mer'i mevzuat kapsamında ülkemiz politikalarının genel çerçevesi kalkınma planları ile çizilmektedir. Kamu için bağlayıcı özel sektör için yönlendirici olan kalkınma planları incelendiğinde; güvenlik konusuna bütünsel yaklaşarak ve özellikle güvenlik kalkınma ilişkisi kurularak 1990'lı yıllar sonrasındaki küreselleşme ve yeni yönetim anlayışı çerçevesindeki değişimlere de paralel olarak, Altıncı Beş Yıllık Kalkınma Planı'ndan itibaren yer verildiği gözlemlenmektedir. Planlarda sosyal güvenlik ve iç güvenlik ağırlıklı olarak yer alan güvenlik konusuna diğer güvenlik konularının eklenmesi, küreselleşmeye bağlı olarak oluşan uluslararasılaşma, yönetişim yaklaşımı ve teknolojik gelişmelere bağlı ve paralel olarak söz konusu olmuştur. Özellikle, 2000'li yıllardan itibaren kamu politikası sürecinde ve örgütlenmesinde yönetiş ağırlıklı uygulamaların giderek daha fazla yer alması ve örgütlenme ve iletişimde teknolojiden daha fazla yararlanılmasıyla güvenlik konusunda da teknolojik gelişmelerin de göz önünde bulundurulması yönünde bir yaklaşım gelişmiş, çevresel güvenlik, gıda güvenliği, siber güvenlik gibi konular dokuz ve onuncu planlardan itibaren ağırlıklı olarak planlarda yer almaya başlamış, tüm ülke düzeyinde önleyici politikalar uygulanması ilkesi benimsenmiştir (URL 1).

Önleyici kolluk faaliyetlerinin kentsel alanlarda uygulanmasının temel amac1 güvenli kentler oluşturulmasıdır. Bu amaç, aynı zamanda taraf olduğumuz uluslararası sözleşmelerin, AB üyelik süreci kapsamında yaptığımız mevzuat uyumunun da bir gereğidir. Örneğin taraf olduğumuz Avrupa Kentsel Şartı kapsamında mekânların suçtan arındırılması gerekmektedir. Ülke olarak imzaladığımız ya da taraf olduğumuz; 1948 tarihli BM İnsan Hakları Evrensel Bildirgesi'nden başlayarak, 1950 Avrupa İnsan Hakları Sözleşmesi, HABİTAT belgeleri, Stockholm ve Rio Bildirgeleri, 1990 Avrupa 
Güvenlik ve İşbirliği Konferansı'nda kabul edilen Paris Şartı, 1992 Avrupa Kentsel Şartı, 1994 Avrupa Kentte Kadınlar Şartı, BM Sürdürülebilir Kentler Programı, Aarhus Sözleşmesi vb. pek çok uluslararası belge kapsamında kentli hakları kapsamında kentsel güvenliği sağlamak ve güvenli kentleri oluşturmak durumundayı. Kentli hakları açısından ülkedeki yasal duruma bakıldığında; 1982 Anayasası'nın 56. Maddesinde "herkesin sağliklı ve dengeli bir çevrede yaşama hakkı bulunduğu ve bunu sağlamanın devletin ve vatandaşların ödevi olduğu" belirtilmektedir. Anayasa'da temel haklarla ilgili kapsamlı düzenlemelere yer verilmiş olup; 17. Maddesinde "Yaşam Hakkı", 21. Maddesinde "Konut Dokunulmazlığı", 23.Maddesinde "Yerleşme ve Seyahat Özgürlüğü", 57.Maddesinde "Konut Hakkı", 74. Maddesinde "Dilekçe Hakkı" düzenlenmiştir. Medeni Kanun'da, kişilerin başkalarına zarar vermeden eylemlerini yapması gerektiği belirtilerek "Komşuluk Hakkı" ile ilgili düzenlemeler yer almakta, Çevre Yasası, yaşam alanımız olan çevrenin korunması ve geliştirilmesini devlet ve vatandaşların sorumluluğuna vererek "Çevre Hakkı" ile ilgili düzenlemelere yer vermektedir. Bu yasaların yanı sıra Belediye Yasası'ndan, İmar Yasası'na pek çok yasal düzenlemede kentli hakları kapsamındaki düzenlemelere ve bunların ihlalinde oluşacak kent suçu ya da kente karşı suç diye tanımlayabileceğimiz suçlara yönelik yaptırımlara yer verilmiştir (Alacadağlı, 1998: 667-671). 2000'li yılar sonrasında çıkarılan bir kanunla (Bilgi Edinme Kanunu), kamu görevlerinin yürütülmesinde açıklık ve şeffaflık ilkeleri bağlamında vatandaşların bilgi edinme hakları düzenlenmiş, 2004 tarihli Türk Ceza Yasası'nda genel güvenlikten, trafik, radyasyon güvenliğine kente karşı işlenecek suçlara yönelik ayrıntılı düzenlemelere yer verilmiştir. 2005 tarihli Kabahatler Kanunu'nun amacı "toplum düzenini, genel ahlak ve sağlık ile çevreyi ve ekonomik düzeni korumak" olarak tanımlanarak kamu düzenini ve başkalarının huzur ve sükununu bozacak kabahatler kentsel yaşamı da kapsayacak biçimde düzenlenmiştir (Ertan, 2014: 87-197). Mer'i mevzuat ve Anayasa'nın 125. Maddesi gereğince herkesin hakları ihlal edildiğinde edenlere karşı -idarenin eylem ve işlemleri de dâhil- yargıya başvuru hakkı vardır. "Ancak başvuru hakkının olmakla birlikte bu hakkın kullanımında kısıtlılıklarından dolayı; örneğin bir başvurunun sonuçlandırılmasının avukatlık ücreti de dahil asgari ücretin alt1 kat1 kadar olması gibi; bu mekanizma pek çalıştırılamamaktadır” (Ertan, 2014: 197-198).

Son yıllarda ülkelerin gündeminde yer alan ve uygulama alanı bulan suçu önleyici kentsel tasarım uygulamaları açısından bakıldığında ülkemizde de bu kapsamda uygulamalar olmakla birlikte bu uygulamaların akıllı binalar gibi yeni yaklaşımlar çerçevesinde gelişmekte olup bütünsel bir kentsel planlamadan uzak olduğu gözlemlenmektedir.

\section{Bayburt'ta Kentleşme ve Kent Güvenliği}

Bayburt, Çoruh Nehri kenarında, denizden 1550 metre yükseklikte, \%45'i dağlık alanlardan oluşan, karasal iklimin hâkim olduğu, $3741 \mathrm{~km}^{2}$ yüzölçümlü ve 80.417 nüfuslu bir ildir. Bayburt, tarihi M.Ö. 3000'li y1llara kadar uzanan, Romalilardan Emevilere, Akkoyunlulara çeşitli devletlere ev sahipliği yapan bir kenttir. 1927 yılına kadar Erzurum'a, bu tarihten sonra Gümüşhane'ye bağlı bir ilçe olan Bayburt, 1989 yılında il olmuştur. Bayburt hem yüz ölçümü hem de nüfus olarak Türkiye'nin en küçük ilidir. Bayburt'un nüfus yoğunluğu $\mathrm{km}^{2} \mathrm{de} \% 22$ olup kent halkının, \%56's1 merkezde, \%44'ü köyde yaşamaktadır. Merkez ilçe ile birlikte üç ilçesi, 170 köyü vardır. Oldukça genç bir nüfusa sahip olup kent nüfusunun \%44,4'ü 25 yaşın altındadır. Nüfus artış hızı ülke genelinin altındadır ve kırsaldan kente göç diğer kentlere göre yüksektir. Ticaret ve 
sanayiin gelişmediği ilde tarım ve hayvancılık başlangıçtan beri ekonomiyi sürükleyici bir rol oynamıştır. Arazi hayvancılık yapmaya çok elverişli olup yüksek mera varlı̆̆1, meraya dayalı besi hayvancılı̆̆ını öne çıkarmıştır (URL2). Sanayi hafif düzeyde olup, ağır sanayi kurulamamıştır. Önde gelen sanayi üniteleri; süt, yem, tuğla fabrikaları ve et kombinasıdır. İldeki topraksız aile oranı (\%26) Türkiye ortalamasının altındadır (Alacadağlı ve Özden, 2016: 168). İşü̈cüne katılım oranı $\% 51,3$, istihdam oran1 $\% 48,1$ 'dir. $\mathrm{Bu}$ istihdamın sektörlere dağllımı; \%44,5 hizmetler, \%44,3 tarım, \%11,2 sanayi sektörü şeklindedir (KUDAKA, 2015: 46-48).

DPT “İller ve Bölgelerin Sosyo-ekonomik Gelişmişlik Araştırması" çalışmasında Bayburt; tarımsal verimliliğin düşük olup, tarım sektöründe önemli bir gizli işsizlik sorununun olduğu beşinci derece gelişmiş iller grubunda yer almaktadır. Nüfusun \%60'ının tarım, hayvancılıkla geçindiği ilde, tarımda işletmelerin küçüklüğü ve verim düşüklüğü gelir yetersizliğine yol açmaktadır. İstihdamda tarım sektörünün payının yüksek olması ücretsiz aile işçiliğini beraberinde getirmekte ve bu ücretsiz aile işçilerinin çoğunluğunu kadınlar oluşturmaktadır. Kent merkezlerinde \%50 civarında olan kayıt dışılık kırsal alanlarda artmakta ve bunun \%63,5'unu kadınlar oluşturmaktadır. Sosyal güvenlik kapsamına alınan nüfusta artış olmasına karşın Bayburt'ta kayıt dışı istihdam oranı ülke ortalamalarının üzerindedir (KUDAKA, 2015: 56). Öte yandan tarımsal işletmelerde işçi istihdamının ihtiyaca cevap verememesi ve yeni işletmelerin kurulmaması nedeniyle halk, genelde yabancı ülkelere ve diğer gelişmiş vilayetlere göç ederek geçimini temin etme yollarını aramaktadır. Giderek azalsa da gurbetçilik ilin geçimini destekleyen bir unsurdur. Örneğin son on y1lda Türkiye'nin nüfusu 1,2 kat artış gösterirken aynı dönemde Bayburt ilinin nüfusu yaklaşık \%9,3 oranında azalma göstermiştir (Alacadağlı ve Özden, 2016: 168). 2011 TUİK verilerine göre Bayburt, 3.461,00 dolar ithalat ve aynı yıl içinde yaptığ1 3.240,00 dolar ihracatla 81 il içerisinde 75. sırada yer almıştır (URL2).2013 y1lında Bayburtlu firmalarca 0,3 milyon dolar ihracat yapılmıştır. Kentin bitkisel ve hayvansal üretiminin Türkiye üretimi içindeki payı \%0,1 ve 0,3 düzeyindedir (TÜİK, 2013: 22-27).

1989'da il olması sonrasında kişi başına düşen ekonomik göstergelerde olumlu bir gelişme söz konusu olan ve 2012 yllında tiyatro salonu, 2017'de sinema salonu faaliyete geçen Bayburt, ekonomik ve sosyal yaşam verilerinin de ortaya koyduğu üzere kentleşme ve gelişme sürecinde olan bir ildir.

2010 yılında yapılan ve bin kişiye düşen suç sayısı Çorum 4,69; Sakarya 8,86; Trabzon; 10,37 olan bir araştırmaya göre Bayburt'ta işlenen asayiş suçu sayısı 897 olup bin kişiye düşen suç sayısı 12.05'tir (URL 3). 2012 yılı TUİK verilerine göre; toplam 82 hükümlü olup suç unsurları yaralama, icra iflas kanunu ve diğer suçlar kategorisindedir. Güvenlik birimlerine gelen 594 çocuktan 177'si suça sürüklenen, 376's1 mağdur. Suç isnat edilen 177 çocuktan 69'unun nedeni yaralama, 47'sinin hırsızlıktır. 2 Şubat'ta yapılan ve ulusal, yerel basında yer alan valilik açıklamasına göre; kentin Bayburt Üniversitesi'nce belirlenen sloganı da "Güvenli Şehrin Huzurlu Üniversitesi" olup, kent, Türkiye'nin en az nüfuslu şehri olmanın yanı sıra en huzurlu, güvenli kentlerinin başında gelmektedir. 2017'de ülkede 3 bin 494 bireysel silahlı olayın yaşanırken, Bayburt'ta ise silahlı hiçbir olay gerçekleşmemiştir. Bu tespitin ve sloganın öneminin vurgulandığı açıklamada; Üniversiteye gelen öğrencilerin de şehrin, huzurlu, güvenli ortamına adapte olup bir asayişsizlik söz konusu olmadan eğitim öğretim hayatlarına devam ettikleri, ilin huzurlu, güvenli bir yurt olması konusuna, burada yaşayan insanlar kadar dışarıdan gelen özellikle öğrencilerin de katkı sağladığı, bu ortamın 
sağlanmasında hala devam eden mahalle odaları geleneğinin etkisine de dikkat çekilmektedir. (URL4). Adalet Bakanlığı'nca yayınlanan Adalet İstatistiklerine göre 2018 y1lında Bayburt'ta ceza mahkemelerinde açılan davalardaki suç sayısı 1843 olup bu suçları işleyenlerin 1607'si erkek, 231'i kadındır (Adalet Bakanlığı, 2019: 103).

\section{Anket ve Mülakat Uygulaması Sonuçları}

Bayburt'ta güvenli kent kavramı konusundaki bilgi, farkındalık, algı ve beklentiler ile güvenli kent yaklaşımı kapsamında yapılması gereken bazı uygulamaların yapılıp yapılmadığını ortaya koymak üzere hem merkezi ve yerel yönetim birimleri yöneticilerine hem de kent halkına anket ve mülakat uygulanmıştır.2018 Eylül ayında ön görüşmeleri ve ilk uygulamaları yapılan anket ve mülakat süreci, 2019 Şubat sonunda ankete ve mülakata daha fazla katılım sağlanamayınca sonlandırılmıştır. Mülakat görüşmelerinde, kent halkına uygulanan ankete benzer şekilde yapılandırılmış soruların olduğu bir görüşme formu kullanılmıştır. Mülakatlarda, demografik bilgilere yönelik soruların yanı sıra güvenli kent kavramı konusundaki bilgi, farkındalık, alg1 ve beklentilere yönelik toplam yedi soru sorulmuştur. Kentlilere uygulanan anketlerde toplam 18 sorunun yanı sıra öneri ve görüş bölümüne de yer verilmiştir. Ankete farklı yaş ve meslek gruplarından 178 kişi, mülakatlara ise ikisi sivil toplum kuruluşu yöneticisi olmak üzere toplamda 14 yönetici katılmıştır.

\subsection{Anket Sonuçları}

Üç bölümden oluşan anketin birinci bölümündeki demografik bilgilerin sonuçlarına göre:

- Ankete katılanların toplamda 71'i(\%39,9'u) öğrenci olup bunlardan, 12'si kısa süreli olarak nitelik gerektirmeyen bir işte çalışmaktadır. 107 kişi ise (\%60,1'i) farklı eğitim, meslek (30 ayrı meslek, ev hanımı ya da işsiz), yaş ve cinsiyet gruplarında kent halkıdır.

- Bunların \%12'si çalışmıyor ya da işsiz olup çalışanların \%8'i özel sektör, \%13'ü kamu, \%5'inin de kendi işidir.

- Ankete katılanların \%50,1'i kadın, \%49,9'u erkektir.

- Ankete katılanların çoğu üniversite mezunu olup iyi eğitimlidir.

Tablo 1. Yaş ve Eğitim Durumları ve Bayburt'ta Yaşama Süreleri Tablosu

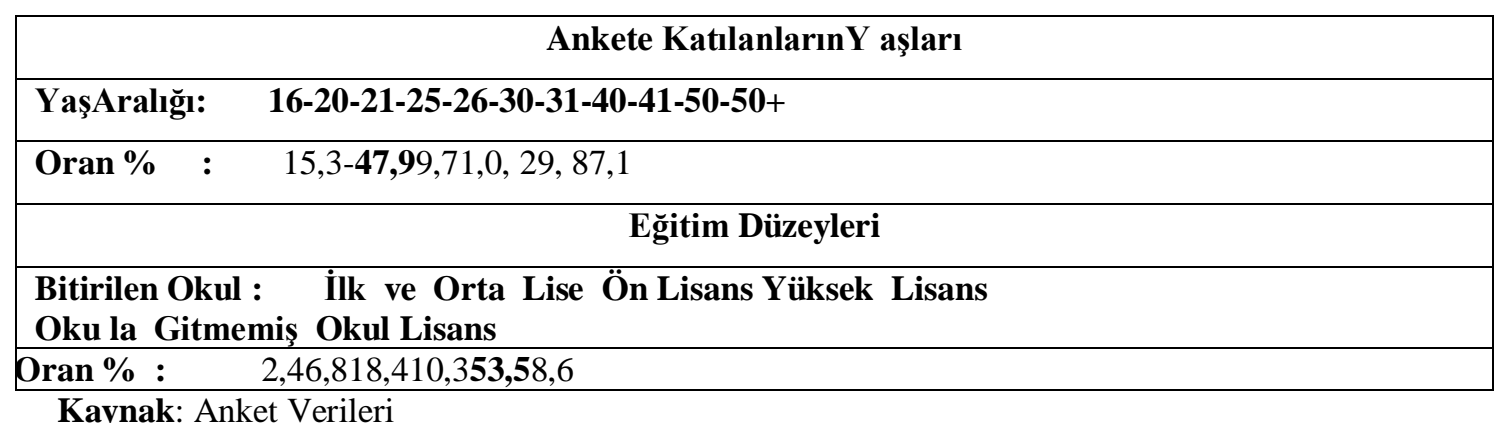

Kaynak: Anket Verileri

Anketin ikinci bölümünde "Güvenli Kent Kavramı” ile ilgili farkındalığı belirlemek üzere sorulan yedi (7) soruya verilen cevaplar aşağıda yer almaktadır: 
Tablo 2. Güvenli Kent Konusunda Farkındalıkla İlgili Veriler

\begin{tabular}{|c|c|c|c|c|}
\hline Soru & \multicolumn{4}{|c|}{ "Güvenlikent” ne demektirbukonudabirbilginizvarmı? } \\
\hline Cevaplar & Evet & Hayır & & Kisr \\
\hline Oran & $\% 48.5$ & $\% 14.2$ & & \\
\hline Soru & \multicolumn{4}{|c|}{ Güvenlikentvekentgüvenliğiaynışeylermidir? } \\
\hline Cevaplar & Evet, aynıdır & Hayır, aynıdeğil & \multicolumn{2}{|r|}{ Birfikrim yok } \\
\hline Oran & $\% 26.2$ & $\% 63.7$ & \multicolumn{2}{|r|}{$\% 10,1$} \\
\hline Soru & \multicolumn{4}{|c|}{ Cevabınız "hayırdeğildir” isebununnedeniniaşağıdakilerdenhangisidahaiyiaçıklar? } \\
\hline Seçenekler & \multicolumn{4}{|c|}{$\begin{array}{l}\text { a. Her ikisiarasındasadecekavramsalolarakfarklılıkvardır. } \\
\text { b. Güvenlikent, kentgüvenliğinin de sağlandığıkenttir. } \\
\text { c. Güvenlikent, kentgüvenliğinin de sağlandığıkenttiramadahafazlası da vardır. } \\
\text { d. Kent güvenliği; kollukişidir, güvenlikent; kentyönetimininişidir. } \\
\text { e. Kent } \\
\text { güventiğidahakapsamlıbirfaaliyettir, } \\
\text { gülikentasayişuygulamalarınınkarşıdayarattığıalgıdır. }\end{array}$} \\
\hline Oran & b. $\% 16.4$ & c. $\% 22.5$ & & $\% 25,7$ \\
\hline Soru & \multicolumn{4}{|c|}{ Güvenli Kent kavramıaşağıdakilerdenhangisini/hangilerinikapsıyor? } \\
\hline Seçenekler & \multicolumn{4}{|c|}{$\begin{array}{l}\text { a. Kent } \\
\text { konuylailgilitümpaydaşlarınkentleilgilikararlarakatılımınınolduğuuygulamaları } \\
\text { b. Önleyiciyaklaşımlaoluşturulankentbilgisistemleri, kentgüvenlik, yönetimsistemleri } \\
\text { c. Güvenlikamaçlıkentseltasarım, } \\
\text { kentselsuçveçöküntüalanlarınınortadankaldırılmasını } \\
\text { d. Kapsayıcıveçokdisiplinliyaklaşımlagüvenlikkonseptini } \\
\text { içerecekşekildeoluşturulanvekentplanlamasındangelişiminetümsüreçlerivekentleilg } \\
\text { ilitümfaaliyetleriiçerir } \\
\text { e. Hepsinikapsıyor }\end{array}$} \\
\hline Oran & a. 7.6 & c. 13.3 & & e. $\quad 49.2$ \\
\hline Verilen & \multicolumn{4}{|c|}{ "Güvenlikent, suçoranlarınındüşükolduğukenttir” cümlesi; } \\
\hline Cevaplar & Doğrubirtanımlamadır. & Eksikbirtanımlamadır. & \multicolumn{2}{|c|}{ Birfikril } \\
\hline Oran & $\% 23.3$ & $\% 62$ & \multicolumn{2}{|r|}{$\% 14.7$} \\
\hline Veri & \multicolumn{4}{|c|}{$\begin{array}{l}\text { "Güvenlikent, o kentteyaşayanlarınkendilerini, kentinherhangibirnoktasında, } \\
\text { gününherhangibirsaatindegüvendehissettiklerikenttir." cümlesiyukarıdakicümleyegöre; }\end{array}$} \\
\hline Cevaplar & Dahadoğrubirtanımlamadır. & Yukardakiileaynıdır. & \multicolumn{2}{|c|}{ Birfikrim yok. } \\
\hline Oran & $\% 51.3$ & $\% 22,2$ & \multicolumn{2}{|r|}{$\% 26.5$} \\
\hline Verilen & \multicolumn{4}{|c|}{$\begin{array}{l}\text { "Güvenlikentkavramı; } \\
\text { kentselekonomikgelişme, } \\
\text { dahakaliteliçevreveyaşamkoşullarınıkısacasürdürülebilirkalkınmayı da içerir” cümlesi; }\end{array}$} \\
\hline Cevaplar & Doğrubirtanımlamadır. & $\begin{array}{l}\text { Kapsamını/amacınısşanbirta } \\
\text { nımlamadır. }\end{array}$ & \multicolumn{2}{|c|}{ Birfikrim yok. } \\
\hline Oran & & & & $\% 25.8$ \\
\hline
\end{tabular}

Kaynak: Anket Verileri

Yukarıda Tablo 2'de yer alan sorulara verilen yanıtlardan da görüldügüü üzere ankete katılanları çoğu "güvenli kent" konusunda bilgisi olduğunu belirtmekte ve güvenli kentle kentsel güvenliğin aynı olmadığını söylemektedir. Tanımsal olarak da içeriği ile ilgili bilgi sahibi oldukları görülmektedir. Bu oranlarda ankete katılan ögrencilerin kent ve yerel yönetimlerle ilgili aldıkları derslerin ve ankete katılanların eğitim düzeylerinin payı olduğu düşünülmektedir.

Anketin "Bayburt Kenti ve Güvenli Kent Uygulamaları" bölümünde sorulan toplamda 18 soruya aşağıdaki cevaplar alınmıştır: 
Tablo 3.Bayburt Güvenli Kent ve Kent Güvenliği Uygulamaları Verileri

\begin{tabular}{|c|c|c|c|c|}
\hline Sorulan & \multicolumn{4}{|c|}{ Bayburt Kenti güvenli bir kenttir. } \\
\hline Cevaplar & Katıliyorum & Katılmiyorum & Kismenkat1liyorum & Birfikrim yok \\
\hline Oran & $\% 45.3$ & $\% 6.7$ & $\% 41.2$ & $\% 6.8$ \\
\hline Sorulan & \multicolumn{4}{|c|}{ Bayburt'tagece-gündüzherhangibirsaatteveherhangibiryerderahatlıkladolaşabilirim } \\
\hline Seçenekler & \multicolumn{4}{|c|}{$\begin{array}{l}\text { a. Evet, dolaşabilirim } \\
\text { b. Hayır, dolaşamam } \\
\text { c. Sadece gündüz dolaşabilirim } \\
\text { d. Gündüz ve gece en geç saat } 22.00 \text { 'ye kadar merkezi/işlek yerlerde dolaşabilirim. }\end{array}$} \\
\hline Oran & a. $\% 45.2$ & b. $\% 16.1$ & $\% 8.4$ & $\% 30.3$ \\
\hline Sorulan & \multicolumn{4}{|c|}{ Bayburtkentindesuçaetkisiolanolumsuzçevrekoşullarımevcutdeğildir. } \\
\hline Cevaplar & Katıliyorum & Katılmiyorum & Kismen katiliyorum & Bir fikrim yok \\
\hline Oran & $\% 45,6$ & $\% 20.4$ & $\% 26$ & $\% 8$ \\
\hline Sorulan & \multicolumn{4}{|c|}{ Bayburt, suç işleme oranının düşük olduğu bir kenttir. } \\
\hline Cevaplar & Katıliyorum & Katılmiyorum & Kismen katıliyorum & Bir fikrim yok \\
\hline Oran & $\% 70.2$ & $\% 12.8$ & $\% 10.7$ & $\% 6.3$ \\
\hline Sorulan & \multicolumn{4}{|c|}{$\begin{array}{l}\text { Bayburt kentinde taciz, cinsel istismar gibi olaylar pek olmaz, bunlar en az görülen } \\
\text { suçlardır. }\end{array}$} \\
\hline Cevaplar & Kat1liyorum & Katılmiyorum & Kismen katıliyorum & Bir fikrim yok \\
\hline Oran & $\% 48.3$ & $\% 25.1$ & $\% 20.4$ & $\% 6.2$ \\
\hline Sorulan & \multicolumn{4}{|c|}{$\begin{array}{l}\text { Bayburt kentinde okul ve çevresinde çocuklar sözlü, fizikselya da duygusal şiddete } \\
\text { maruz kalmazlar. }\end{array}$} \\
\hline Cevaplar & Katıliyorum & Katılmiyorum & Kismen katiliyorum & Bir fikrim yok \\
\hline Oran & $\% 45.3$ & $\% 26.6$ & $\% 17.6$ & $\% 10.5$ \\
\hline Sorulan & \multicolumn{4}{|c|}{ Bayburt kentinde madde kullanımı azdır ve bu konudaki önlemler yeterlidir. } \\
\hline Cevaplar & Kat1liyorum & Katılmiyorum & Kismen katıliyorum & Bir fikrim yok \\
\hline Oran & $\% 41.8$ & $\% 23.3$ & $\% 19,2$ & $\% 15.7$ \\
\hline Sorulan & \multicolumn{4}{|c|}{$\begin{array}{l}\text { Bayburt kentinde, merkezi yerlerde ya da mahalle/ara sokaklarda cinsiyet, kıyafet gibi } \\
\text { faktörlere bağlı olmadan herhangi bir sorun yaşamadan rahatlıkla dolaşılabilir. }\end{array}$} \\
\hline Cevaplar & Kat1liyorum & Katılmiyorum & Kismen kat1liyorum & Bir fikrim yok \\
\hline Oran & $\% 37.2$ & $\% 35.2$ & $\% 24$ & $\% 3.6$ \\
\hline Sorulan & \multicolumn{4}{|c|}{ Bayburt kenti yeterli ulașım altyapısına sahip bir kenttir. } \\
\hline Cevaplar & Katıliyorum & Katilmiyorum & Kismen katıliyorum & Bir fikrim yok \\
\hline Oran & $\% 28.5$ & $\% 52$ & $\% 16.8$ & $\% 2.7$ \\
\hline Sorulan & \multicolumn{4}{|c|}{$\begin{array}{l}\text { Bayburt, kent halkının çevresel gereksinimlerini karşılayacak rekreasyonel (park, piknik } \\
\text { alanları gibi) yaşam alanlarına, donatılara sahip bir kenttir. }\end{array}$} \\
\hline Cevaplar & Katıliyorum & Katılmiyorum & Kismen kat1liyorum & Bir fikrim yok \\
\hline Oran & $\% 40.5$ & $\% 41.2$ & $\% 16$ & $\% 2.3$ \\
\hline Sorulan & \multicolumn{4}{|c|}{$\begin{array}{l}\text { Bayburt kenti sosyal açıdan kent halkının gereksinimlerini karşılayacak, sosyal yaşam } \\
\text { becerilerini geliştirecek yaşam alanlarına, donatılarına sahip bir kenttir. }\end{array}$} \\
\hline Cevaplar & Katıliyorum & Katılmiyorum & Kismen katıliyorum & Bir fikrim yok \\
\hline Oran & $\% 28.5$ & $\% 51.4$ & $\% 17.3$ & $\% 2.8$ \\
\hline Sorulan & \multicolumn{4}{|c|}{$\begin{array}{l}\text { Kentle ilgili mekânsal tasarımı, planlamayı yapanlar, kentsel planlama/tasarımda suçu } \\
\text { engelleyecek, güvenliği kolaylaştıracak önlemleri dikkate almaktadır. }\end{array}$} \\
\hline Cevaplar & Katıliyorum & Katılmiyorum & Kismen katiliyorum & Bir fikrim yok \\
\hline Oran & $\% 32.8$ & $\% 35.2$ & $\% 18.4$ & $\% 13.6$ \\
\hline Sorulan & \multicolumn{4}{|c|}{$\begin{array}{l}\text { Kent güvenliği, bu konudaki görevli olan kesimlerce suç işlemeyi caydıracak şekilde } \\
\text { sağlanmaktadır. }\end{array}$} \\
\hline Cevaplar & Katıliyorum & Katılmiyorum & Kismen katıliyorum & Bir fikrim yok \\
\hline Oran & $\% 45.5$ & $\% 24$ & $\% 15.5$ & $\% 15$ \\
\hline Sorulan & \multicolumn{4}{|c|}{$\begin{array}{l}\text { Bayburt kentinde bir taciz veya şiddet durumunda rahatlıkla güvenlik güçlerine } \\
\text { ulaşılabilir ve yardım sağlanabilir. }\end{array}$} \\
\hline Cevaplar & Katıliyorum & Katılmiyorum & Kismen katıliyorum & Birfikrim yok \\
\hline Oran & $\% 67.3$ & $\% 14.7$ & $\% 12.8$ & $\% 5.2$ \\
\hline
\end{tabular}


Tablo 3'te "Bayburt Kenti güvenli bir kent" olup olmadığını belirlemek üzere sorulan ilk soruya verilen cevaptan görüleceği üzere kısmen cevabı da katıldığında ankete katılanların \%65,9'u Bayburt'un güvenli bir kent olduğunu düşünmektedir. Bayburt'ta herhangi bir saatte ve herhangi bir yerde rahatlikla dolaşabilirim diyenlerin oranı \%45,2 olup çoğunu üniversitede okuyan kız öğrencilerin (\%69'unu) oluşturduğu $\% 30,3$ 'lük bir oran da “Gündüz ve gece en geç saat 22.00'ye kadar merkezi/işlek yerlerde dolaşabilirim" demektedir.

Tablo 3'te yer alan sorulara verilen cevaplara bakıldığında; ankete katılanların $\% \% 70,2$ 'si Bayburt'ta suç işleme oranının düşük olduğunu düşünmektedir. Yine, "kısmen katılıyorum" cevaplarının yarısı katılıyorum yarısı katılmıyorum olarak kabul edildiğinde; ankete katılanların \%50'den fazlası Bayburt'ta suça etkisi olan olumsuz çevre koşulları mevcut olmadığını $(\% 58,6)$; taciz, cinsel istismar gibi olayların az görüldügüünü $(\% 58,5)$; kentte, okul çevresinde çocukların sözlü, fiziksel ya da duygusal şiddete pek maruz kalmadıklarını $(\% 54,1)$; kentte madde kullanımı az olduğunu ve alınan önlemler yeterli olduğunu $(\% 51,4)$, görevlilerce kent güvenliğinin suç işlemeyi caydıracak şekilde sağlandığını $(\% 53,3)$, herhangi bir taciz ya da şiddet durumunda rahatlıkla güvenlik güçlerine ulaşılabildiğini ve yardım sağlanabildiğini $(\% 73,7)$ düşünmektedirler. Bu yanıtlar Bayburt'ta ankete katılanların güvenlik algılarına uygun olarak oluşan güvenlik beklentilerinin genel olarak karşılandığını ortaya koymaktadır.

Ancak, ankete katılanların çoğu (\%44,3’ü), kent planlamasında, kentin mekânsal tasarımında, suçu engelleyecek, güvenliği kolaylaştıracak önlemlerin dikkate alınmadığını da belirtmektedirler. Ayrıca ankete katılanların çoğuna göre; Bayburt kenti, sosyal açıdan ve çevresel açıdan kent halkının gereksinimlerini karşılayacak, sosyal yaşam becerilerini geliştirecek yaşam alanları, donatıları ile yeterli ulaşım altyapısına sahip değildir. Bir diğer önemli husus fikrim yok diyenler hariç ve (her yer de her saatte dolaşılamaz diyenlerin 89'u kadın olmak üzere) çoğunluğa göre (\%49,2'si) Bayburt'ta mahalle/ara sokaklarda cinsiyet, kıyafet gibi faktörlere bağlı olmadan, günün her saatinde herhangi bir sorun yaşamadan rahatlıkla dolaşılamamaktadır.

Tablo 4. Güvenliği Tehdit Eden Sorunla Karşılaşma ve Şiddete Maruz Kalma Durumu

\begin{tabular}{|c|c|c|c|c|}
\hline Sorulan & \multicolumn{4}{|c|}{$\begin{array}{l}\text { Çalıştığınız, eğitim aldığınız ya da barındığınız yerde güvenliğinizi tehdit edecek } \\
\text { herhangi bir durumla karşılaştınız mı? }\end{array}$} \\
\hline Cevaplar & Evet & \multicolumn{2}{|c|}{ Hayır } & Bazı sorunlar yaşadım \\
\hline Oran & $\% 13$ & \multicolumn{2}{|c|}{$\% 71$} & $\% 16$ \\
\hline Sorulan & \multicolumn{4}{|c|}{ Aile içi şiddete maruz kaldınız mı? } \\
\hline Cevaplar & Evet & \multicolumn{2}{|c|}{ Hayır } & Bazı sorunlar yaşadım \\
\hline Oran & $\% 10.1$ & \multicolumn{2}{|c|}{$\% 72.3$} & $\% 17.6$ \\
\hline Sorulan & \multicolumn{4}{|c|}{$\begin{array}{l}\text { Bayburt kenti, güvenlikle ilgili tüm beklentilerimi karşılıyor ve orada yaşamaktan } \\
\text { memnunum }\end{array}$} \\
\hline Cevaplar & Evet & Hayır & Kismen & Bir fikrim yok \\
\hline Oran & $\% 38.4$ & $\% 13.1$ & $\% 44$ & $\% 4.5$ \\
\hline
\end{tabular}

Kaynak: Anket Verileri

Tablo 4'te yer alan yanıtlara göre; ankete katılanların çoğunluğu (\%71 ve \%72 düzeyinde); çalıştığınız, eğitim aldığı ya da barındığ 1 yerde güvenliğini tehdit edecek herhangi bir durumla karşılaşmamış ve aile içi şiddete maruz kalmamıştır.

Ankette kendilerine yöneltilen; "Sizce kent güvenliğini sağlama aşağıdaki kurum ya da kişilerden hangisinin/ hangilerinin işidir?" sorusuna ankete katılanların \% $\% 2,5^{\prime} \mathrm{i}$ 
"Polis/emniyet güçleri”nin cevabını vermiştir. Bu işin aynı zamanda yerel yönetimler, vali/il yönetimi ve kent halkının da sorumluluğunda olduğunu düşünenlerin oranı ise $\% 27,5$ 'dir.

\subsection{Mülakat Sonuçları}

Kent güvenliği ve güvenli kent konusunda yapılacak çalışma ile ilgili olarak bilgi verilerek ve hazırlanan soru kâğıdı önceden gönderilerek görüşmeyi kabul eden merkezi ve yerel yönetimlerde; vali yardımcısı, belediye başkanı, il müdürü, daire başkanı olarak görev yapan 12 kamu görevlisi ve ayrıca iki sivil toplum kuruluşu yöneticisi ile (toplamda 14 kişi) görüşüldü. Bu yöneticilere demografik bilgilerin yanı sıra güvenli kent, kent güvenliği kavramları ile ilgili soruların yanı sıra görev alanlarında kent güvenliği/güvenli kent konusunda ne tür çalışmalar yaptıkları soruldu.

- Mülakat yapılan yöneticilerin 12'si erkek ikisi kadın olup bunlardan ikisi yüksek lisans, 10'u lisans, ikisi ön lisans mezunudur.

- Altıs1 30 yıldan fazla Bayburt’ta yaşıyordur. 11-20 yıl arasında yaşayan kişi sayısı dört olup diğerleri 1-5 yıldır Bayburt’ta yaşamaktadır. Dördü hariç hepsi 11 yılı aşkın süredir Bayburt'ta çalışmaktadır.

- "Güvenli Kent" nedir sorusuna bu konuda "kısmen bilgim var" diyen dördünün dışında diğerleri "'Güvenli Kent" ne demektir bildiklerini ve bu konuda bilgileri olduğunu söylemişlerdir.

- Güvenli kent ve kent güvenliği aynı şeyler midir? sorusuna güvenli kent kavramını bildiğini söyleyen biri "aynıdır" diye cevap verirken üçü 'birbirine yakın' demiştir. Kavramla ilgili kısmen bilgim var diyen iki kişi ise 'Bunu değerlendirmek için yeterli bilgim yok" demiştir.

- Güvenli kent ve kent güvenliği aynı şeyler değildir" diyen dördü bunun nedenini 'Güvenli kent, kent güvenliğinin de sağlandığı kenttir ama daha fazlası da vardır' diye belirtmiştir.

- "Birbirine yakın" diyen üç kişiden ikisi; "sanırım” diye başlayarak yukardaki nedenden ötürü birbirinden biraz farklı olduğunu belirtmişlerdir.

- "Güvenli Kent" kavramı aşağıdakilerden hangisini/hangilerini kapsıyor? şeklinde sorulan ve aşağıdaki seçeneklerin sunulduğu soruya sadece ikisi hepsini kapsıyor demiştir. Biri 'cc' diğerleri 'd" seçeneğini seçmiştir.

a. Kent halkının, konuyla ilgili tüm paydaşların kentle ilgili kararlara katılımının olduğu yönetişim uygulamaları

b. Önleyici yaklaşımla oluşturulan kent bilgi sistemleri, kent güvenlik yönetim sistemleri

c. Güvenlik amaçlı kentsel tasarım, kentsel suç ve çöküntü alanlarının bertarafi

d. Kapsayıcı ve çok disiplinli yaklaşımla güvenlik konseptini de içerecek şekilde oluşturulan ve kent planlamasından gelişimine tüm süreçleri ve kentle ilgili tüm faaliyetleri içeren genel çerçeve

e. Yukardakilerin hepsini, kapsiyor

- "Güvenli kent, sadece suç oranlarının düşük olduğu kenttir" cümlesine, "sanırım bu kavram kent güvenliğinde biraz farklı" diyen ikisi dışında hepsi, "eksik tanımlama" demişlerdir.

- "Güvenli kent kavramı; kentsel ekonomik gelişme, daha kaliteli çevre ve yaşam koşullarını kısaca sürdürülebilir kalkınmayı da içerir” cümlesine; hepsi evet kapsıyor derken sadece birisi ' 'bir fikrim yok' demiştir. 
- Mülakatın, "Bayburt’ta Kentsel Güvenlik/Güvenli Kent Uygulamaları” bölümündeki Bayburt'un güvenli bir kent olup olmadığı sorusuna; suç işleme oranlarının düşüklügünü belirterek "kısmen güvenlidir" diyen iki kişi hariç tüm yöneticiler "Bayburt güvenli bir kenttir" demişlerdir. Bu konuyla ilgili il müdürü; "Bayburt'un suçla ilgili sıralama yapılan hemen her alanda oranın en düşük olduğu dört il içinde yer aldığını" belirtmiştir.

- Mülakata katılanların dördü (ki bunların biri asayişle ilgili alanda çalışan il müdürü)kent güvenliğini sağlamanın; 'kent halkı ile birlikte STK'lar da dahil merkezi yerel tüm kent yönetiminin işi olduğunu" düşünmektedir. Diğer yöneticiler kolluk anlayışı ile 'bu iş emniyet valiliğin işidir'" demektedir.

- Kurumunun güvenli kent yaklaşımı çerçevesindeki görevlerini ve bu kapsamda yaptıklarını üç kişi kısaca tanımlarken bu konuda yapılanlara kapsamlı olarak değinen biri asayişi sağlamakla görevli il yöneticisi olmak üzere üç yöneticidir. Kendi görev alanlarına değinerek güvenli kentle ilgili olarak da bir şeyler yapmalıyız diyen dört kişidir. Biri sivil toplum kuruluşu yetkilisi olmak üzere iki yönetici bu konuların doğrudan kendilerini ilgili olmadığını söylemişlerdir.

- Kurumunun güvenlikle ilgili çalışmalarını anlatanlardan ikisi güvenliği planlamadan uygulamaya tüm aşamalarda güvenlik konusunu dikkate aldıklarını söylerken, biri uygulama aşamasında dikkate aldığını söylemiş, biri merkezin bu konuda yaptığ 1 yıllık planlamalara uygun ancak inisiyatif alarak daha kapsamlı ve işbirliğine, iletişimi güçlendirmeye yönelik çalışmalar yaptığını belirtmiştir. Özellikle asayişle ilgili bu birim yöneticisinin görüşme sırasında dokümanlarını da sunduğu çalışmaların katılımcı anlayışla yapıldığı ve üniversite öğrencileri, ilköğretim öğrencilerini kapsadığı görülmüştür. $\mathrm{Bu}$ birimce bu kapsamda projeler de yürütülmekte olup birim mevzuatı gereği, mart ve eylül aylarında Vali ya da yardımcısı başkanlığında ve STK temsilcisi de dahil il yöneticilerinin katıldığı bir "Güvenlik Danışma Kurulu Toplantısı" düzenlemektedir. İl Müdürü tarafından verilen bilgiye göre geçen Eylül ayında yapılan son toplantıda ildeki güvenlik sorunları tartışılmış, il düzeyinde alınacak güvenlik önlemleri ve yapılacak çalışmalarla ilgili kararlar alınmıştır.

\section{Sonuç ve Değerlendirme}

Kentlerin temel kuruluş amacı, insanların barınmasını, çalışmasını, dinlenmesini, sosyalleşmesini ve diğer ihtiyaçlarını karşılayarak güven içinde yaşamlarını devam ettirmesini sağlamaktır. Bu amaç kapsamında Bayburt örneğine bakıldığında; literatür taraması ve anket verileri, bu alanlardan asayiş anlamında güvenlik, barınma dışında kalanların kısmen karşılanabildiğini ya da karşılanamadığını ortaya koymaktadır. 1989 yılında il olan, bu tarih sonrasında hem organizasyonel hem de imar açısından yeniden inşa edilen ve edilmeye devam edilen, üniversite kurulmasıyla bu kapsamdaki çalışmaların hız kazandığı Bayburt kenti yaptığı çalışmalarla o yıldan günümüze epeyce mesafe almakla birlikte halen kentleşme sürecinde olan bir kenttir.

$\mathrm{Bu}$ çalışma kapsamında yapılan literatür taramalarının yanı sıra ve bir STK tarafından yapılan ve Eylül 2018'de konuyla ilgili akademisyen, uzmanların katılımıyla Bayburt'ta gerçekleştirilen "Bayburt'ta Kentleşme Kentlilik Bilinci Kongresi”"nde sunulan anketlerin verileri de, kentin, kentlileşme noktasında kente özgü davranışları edinme açısından zamana ihtiyacı olduğunu ortaya koymaktadır. Öte yandan bu çalışma kapsamında kent güvenliği, güvenli kent konusunda yapılan anket ve mülakatların 
sonucu, Bayburt'ta güvenlikle ilgili olarak yapılan çalışmaların birçok ilde olduğu gibi ağırlıklı olarak asayiş temelli olduğunu göstermektedir. Trafik güvenliğinden çevre güvenliğine, sağlık güvenliğine yaşanan kimi olaylardaki uygulamalar ile kent yöneticileriyle yapılan mülakatlara verilen cevaplar bu çalışmaların asayişi sağlama temelli kent güvenliği anlayışı ile yapıldığını ortaya koymuştur. Kenti yönetenler bunu açıkça ifade ederken güvenli kent anlayışı ile bu uygulamaları yapma konusunda da oldukça isteklidirler. Anket ve mülakat sonuçları kent güvenliği ve güvenli kent konusunda fikir sahibi olunduğunu ama bu sürece etkin olarak katılacak ve uygulamayı sağlayacak yeterli bilgi altyapısına, teknik donanıma, insan gücüne sahip olunmadığını göstermektedir.

Yöneticilerce, Bayburt'un sloganında yer alan "güvenli kent" kavramının dayanağının suç işleme oranlarındaki düşüklüğge dayalı güvenli kent algısı olduğu net bir şekilde ifade edilmiştir. Öte yandan kent yöneticileri, güvenli kent kriterlerini sağlamak üzere üniversitenin de katkısıyla, bu konuda gerekli çalışmaları yapabileceklerini belirtmişlerdir. $\mathrm{Bu}$ bağlamda Bayburt'un kendini tanımlamada kullandığ1 ve bir anlamda kent vizyonu olarak ortaya koyduğu bu vizyona ulaşmak, güvenli kent olmanın gereklerini tam olarak sağlayabilmek ve literatür taramasında ortaya konulan "güvenli kent kriterleri”ni uygulamaya geçirmek için çalışmalar yapması gerekmektedir. Çünkü asayiş temelli yaklaşımlarla sağlanan ve güvenli kent sıralamasında ön sıralarda yer almasını sağlayan suç işleme oranlarındaki düşüklük güvenli kentin sadece kentsel güvenlik boyutunu oluşturmakta olup Bayburt'taki uygulamaların güvenli kent yaklaşımının gerektirdiği bütünsel, multidisipliner yaklaşımla, kent halkı da dahil tüm tarafların katılımıyla kent planlamasından gelişimine tüm süreçleri ve kentle ilgili tüm faaliyetleri içeren bir genel çerçevede yap1lması gerekmektedir.

Bu süreçte; işbirliğine açık mekanizmalarla, bilimsel bilgi altyapısını sağlamada ve yönlendirmede Üniversite'nin; halkın katılımını ve yapılacak çalışmaların daha geniş bir kitleye ulaşmasını sağlamada, yeni bir anlayışla daha etkin kullanılacak şekilde yapılandırılarak aktif biçimde kullanılacak mahalle odalarının; güvenli kent anlayışını yerleştirme, uygulamasını başlatma, yürütme ve sürdürülebilirliğini sağlamada yararlı olacağ 1 düşünülmektedir.

\section{Kaynakça}

Adalet Bakanlığı (2019). Adalet İstatistikleri 2018, Ankara: Adli Sicil ve İstatistik Genel Müdürlüğü Resmi İstatistik ProgramıYayını.

Alacadağlı, E.(1998). Kent Suçu Kente Karşı Suç, İller ve Belediyeler Dergisi, Sayı 637, Ankara: Genç Ofset

Alacadağlı E. ve Özden, E. (2016). 2.Annual Meeting, Sosyoeconomi Society, October 28-29, 2016 Amsterdam/Hollanda Proceedings Book, Ahmet B. Yereli ve Altuğ M. Köktaş (Ed.) içinde Urban Migration, Role of Universities in Development and Bayburt as an Example: Ankara, Sonçağ Yayıncılık Matbaacılık, 168

Aytaç, S., Derdiman R.C., Baştürk, Ş. Öngen, B. (2015). Kent Güvenliği Olarak Suç Korkusu: Bursa Örneği, Süleyman Demirel Üniversitesi Mühendislik Bilimleri ve Tasarım Dergisi3(3), OS: Ergonomi 2015, Isparta: 259-267

Derdiman, R. C. (2010). "Kentleşmenin Suça Etkisi ve Kentlilerin Suçla Mücadelesinin Sosyal ve Hukuki Boyutları" Çağdaş Yerel Yönetimler, 19 (3), Temmuz 2010, Ankara: TODAİE Yayınları, ss. $49-73$ 
Ertan, A. K. (2014). Kent ve Kentli Hakları, Ankara: TODAİE Yayınları

Gündüzöz, İ. (2016). “Türkiye ve Dünyada Güvenli Kent Yaklaşımı: Kentsel Güvenlik mi? Güvenli Kent mi?”, Türk İdare Dergisi, Sayı 483, Ankara: İçişleri Bakanlığı Yayını

Kaypak, Ş. (2016). "Kentsel Bir Sorun Olarak Kentsel Güvenlik", Akademik Sosyal Araştırmalar Dergisi, Y1l: 4, Sayı: 33, Kasım 2016, ss. 35-50

Keleş, R. (2016). Kentleşme Politikası, 15. Baskı, Ankara: İmge Kitapevi

KUDAKA, Bayburt Sosyal Yapı Analizi, KUDAKA Yayınları, Erzurum:2015

Kula, S ve Çakar, B. (2015). "Maslow İhtiyaçlar Hiyerarşisi Bağlamında Toplumda Bireylerin Güvenlik Algısı ve Yaşam Doyumu Arasındaki İlişki”, Bartın Üniversitesi İ.I.B.F. Dergisi, Cilt: 6 Sayı: 12, ss. $191-210$

Payam, M.M. (2018). "Emniyet, Güvenlik, Kent Emniyeti ve Kent Güvenliği: Kavramsal Bir Analiz", Avrasya Terim Dergisi, 6 (1), ss.15-25

Sümer, Ç.G. (2018). Kamu Yönetimi Ansiklopedisi, Y. M. Işıkcı ve E. Alacadağlı (Ed) içinde Kentsel Güvenlik, Ankara: Astana Yayınları

TDK-Türk Dil Kurumu (2005), Türkçe Sözlük. 10. Baskı Ankara

TÜIK.(2014). Seçilmiş Göstergelerle Bayburt 2013. Ankara: TÜİK Matbaası,

URL 1; http://www.kalkinma.gov.tr/Pages/KalkinmaPlanlari.aspx , Erişim, 8 Eylül 2018

URL 2;http://www.bayburt.gov.tr/ekonomi, Erişim, 8 Eylül 2018

URL 3;http://www.akasyam.com/turkiyenin-il-il-suc-oranlari-2811, Erişim, 8 Eylül 2018

URL 4; http://www.milliyet.com.tr/huzur-ariyorum-diyenlerin-sehri-bayburt-bayburt-yerel haber 2570838/, Erişim, 8 Eylül 2018

Zerrin Toprak (2014), Yerel Yönetimler, 9. Baskı, Ankara: Siyasal Kitapevi 